\title{
PERANCANGAN SISTEM INFORMASI GEOGRAFIS HASIL PRODUKSI PERTANIAN BAWANG MERAH DI KABUPATEN NGANJUK MENGGUNAKAN METODE K-MEANS
}

\author{
Joseph Stenica Hariyono, Hani Zulfia Zahro', Renaldi Primaswara \\ Program Studi Teknik Informatika S1, Fakultas Teknologi Industri \\ Institut Teknologi Nasional Malang, Jalan Raya Karanglo km 2 Malang, Indonesia \\ 1718064@scholar.itn.ac.id
}

\begin{abstract}
ABSTRAK
Bawang merah adalah salah satu tanaman hortikultura yang banyak dikonsumsi oleh masyarakat di semua kalangan. Maka bawang merah menjadi tanaman yang banyak diproduksi karena dibutuhkan oleh masyarakat, salah satu daerah penghasil bawang merah terbesar di Provinsis Jawa Timur adalah Kabupaten Nganjuk yang tiap tahunnya menghasilkan panen bawang merah yang melimpah. Dengan hasil panen yang cukup besar tersebut pertahunnya maka Badan Dinas Pertanian Kabupaten Nganjuk mengalami kesulitan untuk mendata hasil panen bawang merah di Kabupaten Nganjuk. Dibuatlah sistem informasi geografis berbasis website untuk mempermudah memproses data hasil panen dengan membangun sistem informasi geografis pertanian bawang merah di Kabupaten Nganjuk yang dapat mengelola data secara lebih cepat dan terperinci dengan baik menggunakan metode yang diterapkan yaitu metode K-Means Clustering. Data Kabupaten Nganjuk tahun 2016 sampai tahun 2020 yang per tahunnya memiliki 19 data kecamatan sehingga secara keseluruhan total data selama 5 tahun yaitu 95 data Pada titik pusat yang sudah ditentukan akan menghasilkan proses iterasi menggunakan data panen bawang merah. Berdasarkan hasil pengolahan data, hasil perhitungan menggunakan metode K-Means Clustering data tahun 2017, 2018, 2020 berakhir pada iterasi ke 6 sedangkan data tahun 2016 dan 2019 berakhir pada iterasi ke 7. Sehingga hasil akhir pengolahan data menggunakan metode clustering dapat menyelesaikan permasalahan pengelompokkan data hasil panen bawang merah di Kabupaten Nganjuk.
\end{abstract}

Kata Kunci : Bawang Merah, Clustering, K-Means Clustering

\section{PENDAHULUAN}

Bawang merah merupakan salah satu komoditas tanaman hortikultura yang banyak dikonsumsi masyarakat juga salah satu hasil panen yang mempunyai prospek dagang yang baik di Indonesia dan termasuk dalam produk unggulan Indonesia. Sebagai tanaman hortikultura yang banyak dikonsumsi dikalangan masyarakat, bawang merah memiliki potensi pengembangan yang masih terbuka lebar di dalam negeri bahkan luar negeri. Oleh karena itu bawang merah menjadi salah satu tanaman produksi yang sering dicari dan diminati banyak orang. Indonesia saat ini sudah mengkonsumsi bawang merah hingga 650.000 ton, dan masih terus bertambah sekitar $5 \%$ pertahunnya seiring berkembangnya industri pengolahan serta meningkatnya jumlah penduduk di Indonesia.

Kabupaten Nganjuk adalah salah satu Kabupaten yang menjadi pusat penghasil panen bawang merah di Provinsi Jawa Timur. Bahkan Kabupaten Nganjuk termasuk dalam salah satu sentra penghasil bawang merah terbesar yang ada di Provinsi Jawa Timur. Kabupaten Nganjuk merupakan salah satu daerah dengan lahan tanaman bawang merahnya cukup besar. Luas panen petani bawang merah bisa mencapai 12.000 hektare (ha) per tahun dengan produktivitas sekitar 12 ton per hektare, sehingga menjadi yang terluas di Jawa Timur. Varietas bawang merah yang sering ditanam petani di Kabupaten Nganjuk antara lain Tajuk Bauci,
Manjung, Trisula Katumi, Philip dan Sanren. Ratarata produktivitas bawang merah varietas Tajuk dan Bauci bisa mencapai 15 hingga 20 ton per hektare.

Sebagai sentra penghasil bawang merah di Jawa Timur, bukan hal yang mengherankan bagi warga Kabupaten Nganjuk bila di mana-mana terlihat banyak orang menanam, memanen, menjemur, atau memperjual belikan bawang merah.

Untuk itu dalam memenuhi kebutuhan bawang merah, dinas pertanian berupaya untuk mengoptimalkan hasil pertanian dengan mengelompokkan daerah yang menghasilkan tanaman bawang di derah Jawa timur khususnya di Kabupaten Nganjuk dengan metode clustering. Bertujuan untuk mengetahui daerah kecamatan mana saja yang menghasilkan produksi bawang merah. Untuk mengelompokkan dapat menggunakan metode algoritma K-Means. Keitka data sudah dikelompokkan menggunakan algoritma K-Means dapat memepermudah dinas pertanian dalam mengolah data hasil pertanian di tiap kecamatan agar mengetahui daerah yang berpotensi mana yang menghasilkan bawang merah sedikit, sedang, dan terbanyak.

\section{TINJAUAN PUSTAKA}

\subsection{Analisis Kebutuhan Fungsional}

Analisis kebutuhan fungsionalitas menggambarkan proses kegiatan yang akan di terapkan dalam sebuah sistem. Pada website Sistem 
Informasi Geografis ini memiliki kebutuhan Fungsinonal sebagai berikut:

1. Website dapat menampilkan informasi data peta geografis umum di Kabupaten Nganjuk.

2. Website dapat menampilkan maps yang terdapat point daerah penghasil bawang merah.

3. Website dapat menghitung pengelompokkan data komoditi bawang merah serta data panen.

4. Website dapat menampilkan data informasi produksi panen bawang merah di Kabupaten Nganjuk.

5. Website dapat menambah, mengedit, dan menghapus data panen bawang merah.

\subsection{Analisis Kebutuhan Nonfungsional}

Analisis kebutuhan nonfungsional menggambarkan batasan layanan pada sistem. Pada website Sistem Informasi Geografis ini Kebutuhan batasan sistem diperlukan untuk mengimplementasikan sistem informasi geografis berbasis web sebagai berikut:

1. Website dihosting pada webhost.

2. Website diakses menggunakan browser yang terhubung di internet.

3. Admin harus menggunakan username dan password untuk login.

4. Seluruh Database terintegrasi dalam satu website.

5. Website dapat diakses melalui multiplatform seperti pc atau smartphone

\subsection{Struktur Menu}

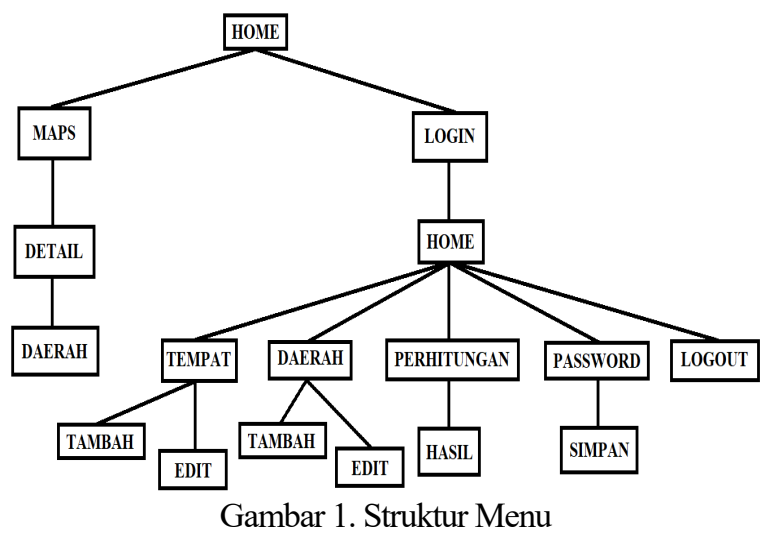

Pada Gambar 1 hamalan utama memiliki akses ke beberapa menu sebagai user hanya dapat mengakses menu maps, tetapi admin dapat mengakses menu maps dan login.

Ketika admin sudah login maka akan memiliki akses tambahan sebagai admin yaitu menu tempat, daerah, perhitungan, password, dan logout. Pada menu tempat, admin dapat menginputkan, mengubah, dan menghapus data wilayah kecamatan yang diinginkan lalu pada daerah juga sama seperti menu tempat tetapi wilayah yang dimasukkan lebih terpencil seperti desa, pada perhitungan dapat menghitung clustering data hasil panen yang diinputkan sesuai tahun, pada password admin dapat mengubah password sesuai keinginan dan terakhir menu logout untuk keluar sebagai admin.

\subsection{Metode Penelitian}

K-Means Clustering adalah proses membagi data menjadi berkelompok dengan cluster yang memiliki kemiripan sesuai dengan atribut data tersebut. Setiap cluster awal sudah ditentukan secara acak untuk proses awal secara random. K-Means termasuk dalam partitioning clustering adalah tiap data yang dimiliki harus termasuk dalam bagian cluster tertentu sesuai kemiripan data dengan titik pusat dan memiliki kemungkinan tiap data termasuk dalam salah satu cluster ketika diproses, pada proses berikutnya data dapat berpindah ke cluster yang lain.

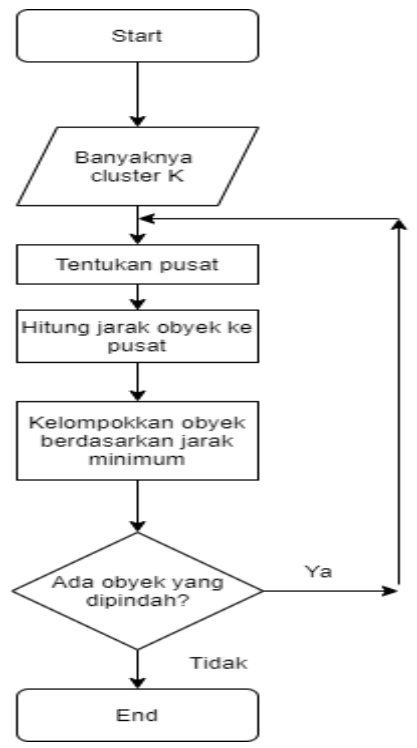

Gambar 2. Flowchart Proses K-Means Clustering

Proses clustering selanjutnya akan dilakukan proses pengulangan langkah-langkah berikut hingga mendapat hasil:

a. Menentukan banyak cluster

Pertama untuk melakukan proses clustering yaitu menetapkan berapa banyak cluster yang akan dibentuk. Pada perhitungan ini, ditetapkan tiga cluster yaitu cluster untuk kecamatan dengan produksi bawang merah sedikit $(\mathrm{C} 0)$, produksi sedang $(\mathrm{C} 1)$ dan produksi banyak $(\mathrm{C} 2)$.

b. Menentukan titik pusat awal (centroid)

Selanjutnya yaitu menetapkan banyak cluster yang akan dibentuk, lalu menetapkan titik pusat awal (centroid) dari masing-masing cluster. Penetapan titik pusat awal ditentukan secara random (acak). Maka dipilihlah pada perhitungan ini adalah C3 untuk titik pusat daerah dengan produksi bawang merah tinggi yang memiliki titik pusat (2000, 5000), selanjutnya C2 untuk titik pusat daerah dengan produksi sedang yang 
memiliki titik pusat $(500,1000)$, terakhir C1 untuk titik pusat daerah produksi bawang merah sedikit dengan titik pusat $(50,100)$.

c. Menghitung jarak setiap objek ke titik pusat (centroid)

Setelah melakukan penentuan titik pusat awal maka dilakukan proses menghitung setiap jarak data dengan titik pusat yang sudah dipilih sebelumnya. Digunakan Rumus berikut untuk menghitung jarak setiap objek ke titik pusat sebagai berikut :

$$
d(x, y)=\sqrt{\left(x_{1}-y_{1}\right)^{2}+\left(x_{2}-y_{2}\right)^{2}+\ldots+\left(x_{p}-y_{p}\right)^{2}}
$$

Dimana $x$ adalah data produksi bawang merah, lalu y adalah titik pusat awal yang ditentukan secara acak.

Tabel 1. Data Hasil Panen Bawang Merah Tahun 2016

\begin{tabular}{|c|l|c|c|c|c|}
\hline No & Kecamatan & Luas Panen (ha) & Produks $(\mathrm{kw})$ & Produktivitas (kw/ha) & Tahun \\
\hline 1 & Sawahan & 20 & 1400 & 70 & 2016 \\
\hline 2 & Ngatos & 4 & 281 & 70.25 & 2016 \\
\hline 3 & Berbek & - & - & - & 2016 \\
\hline 4 & Loceret & 5 & 433 & 86.6 & 2016 \\
\hline 5 & Pace & 3 & 330 & 110 & 2016 \\
\hline 6 & Tanjunganom & 14 & 1160 & 82.85714286 & 2016 \\
\hline 7 & Prambon & 1 & 21 & 21 & 2016 \\
\hline 8 & Ngronggot & 2 & 163 & 81.5 & 2016 \\
\hline 9 & Patianrowo & - & - & - & 2016 \\
\hline 10 & Baron & 2 & 228 & 114 & 2016 \\
\hline 11 & Gondang & 2812 & 290045 & 103.1454481 & 2016 \\
\hline 12 & Sukomoro & 1803 & 164716 & 91.35662784 & 2016 \\
\hline 13 & Nganjuk & 285 & 26441 & 92.7754386 & 2016 \\
\hline 14 & Bagor & 2626 & 315458 & 120.1287129 & 2016 \\
\hline 15 & Wilangan & 1027 & 107850 & 105.0146056 & 2016 \\
\hline 16 & Rejoso & 3397 & 399029 & 117.4651163 & 2016 \\
\hline 17 & Ngguyu & 224 & 15408 & 68.78571429 & 2016 \\
\hline 18 & Lengkong & 15 & 1329 & 88.6 & 2016 \\
\hline 19 & Jatikalen & 4 & 386 & 96.5 & 2016 \\
\hline & & & & & \\
\hline
\end{tabular}

Berikut contoh data untuk perhitungan jarak data dengan titik pusat. Contoh untuk kecamatan Sawahan menggunakan data tahun 2016 memiliki luas panen 20 dan hasil produksi 1400, maka diperoleh hasil perhitungan jarak data pada kecamatan Sawahan dengan pusat cluster awal adalah:

$$
\begin{array}{ll}
d_{11}=\sqrt{(20-50)^{2}+(1400-100)^{2}} & =1300.346108 \\
d_{12}=\sqrt{(20-500)^{2}+(1400-1000)^{2}} & =624.8199741 \\
d_{13}=\sqrt{(20-2000)^{2}+(1400-5000)^{2}} & =4108.576396
\end{array}
$$

d. Mengelompokkan obyek berdasarkan jarak minimum

Langkah terakhir clustering yaitu dengan mengelompokkan objek berdasarkan jarak minimum data dengan titik pusatnya. Berikut terdapat contoh menggunakan data kecamatan Sawahan yang telah di hitung di langkah sebelumnya.

$$
\begin{aligned}
& d_{11}=1300.346108 \\
& d_{12}=624.8199741 \\
& d_{13}=4108.576396
\end{aligned}
$$

e. Maka, jarak minimum untuk kecamatan Sawahan pada tahun 2016, terdapat pada cluster 1, jadi kecamatan Sawahan pada tahun 2016 dikelompokkan sebagai kecamatan dengan produksi bawang merah sedang.

\section{IMPLEMENTASI}

Dalam tahap ini akan dijelaskan langkahlangkap pengoperasian programbeserta contoh gambar.

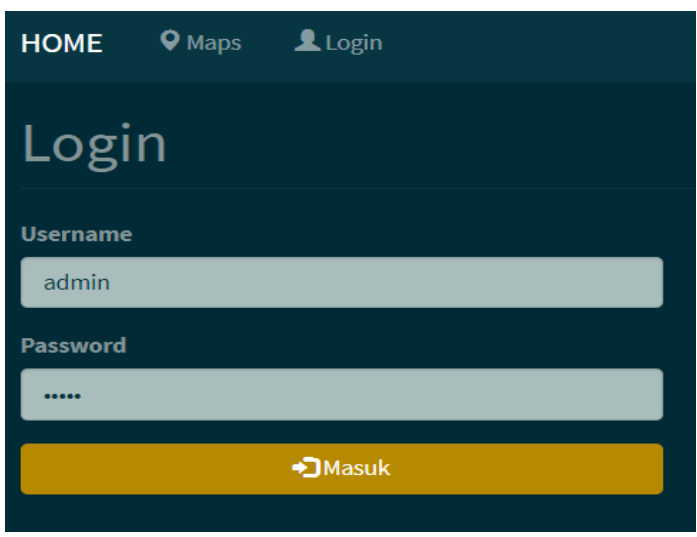

Gambar 3. Halaman login

Gambar diatas adalah tampilan dari halaman login yang dimana kita harus login terlebih dahulu untuk memiliki hak akses sebagai admin yang nantinya akan memasukkan data hasil panen bawang merah.

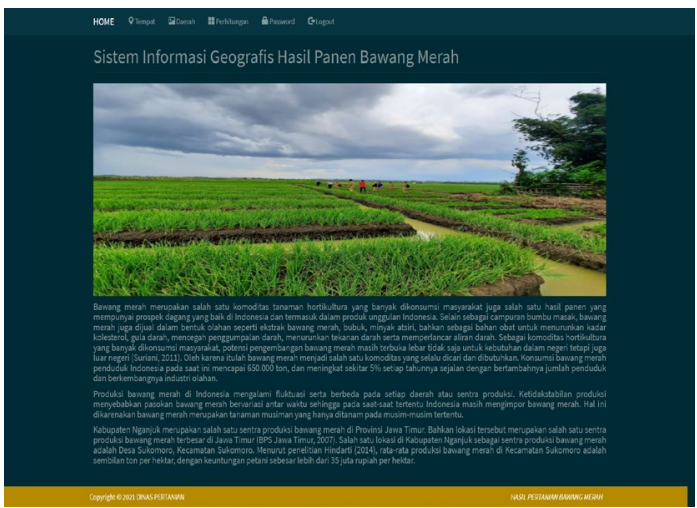

Gambar 4. Halaman Utama Sebagai Admin

Setelah login maka kita akan masuk pada tampilan home atau halaman utama dimana ada beberapa menu yang hanya bisa diakses oleh seorang admin. 


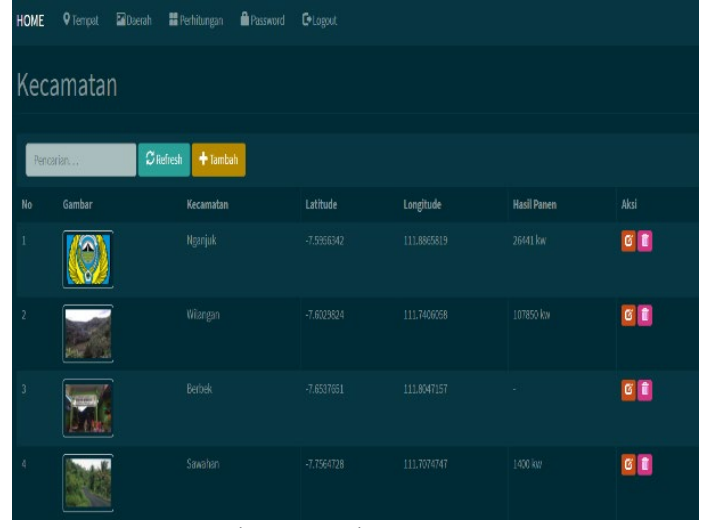

Gambar 5. Halaman Tempat

Pada halaman tempat digunakan untuk menginput, mengubah, atau menghapus data yang diinginkan sebagai seorang admin. Ada beberapa tabel yang terdiri dari nomer, gambar, kecamatan, latitude dan longitude sebagai titik koordinat letak atau posisi pada kecamatan, terakhir yaitu aksi yang berguna untuk mengedit dan menghapus data.

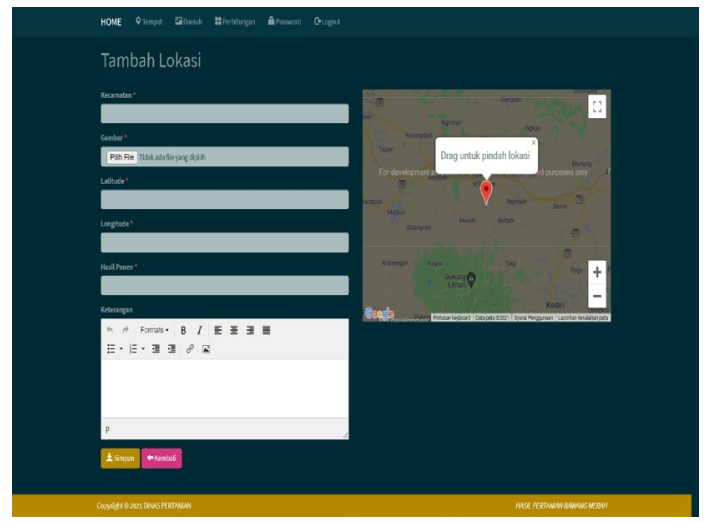

Gambar 6. Halaman Tambah Lokasi

Pada halaman tambah lokasi dapat menambahkan lokasi kecamatan dan berat total panen yang dihasilkan dan gambar pada kecamatan tersebut yang nantinya data tersebut akan masuk ke halaman tempat dan tampil pada tabel halaman tersebut.

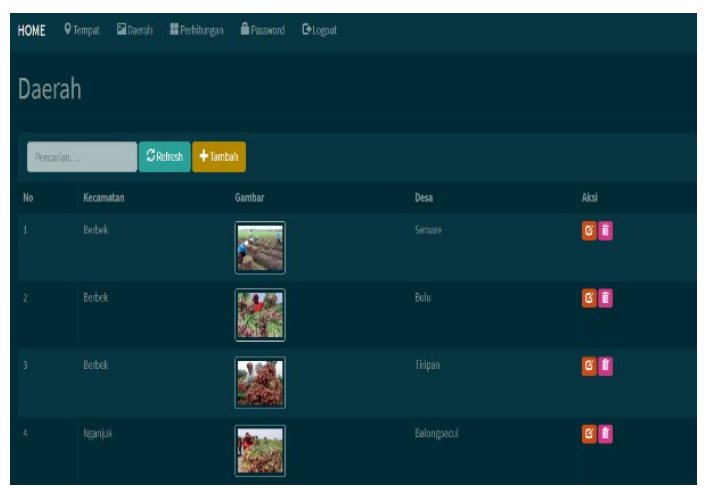

Gambar 7. Halaman Daerah

Di halaman daerah kita bisa menambah daerah seperti desa pada kecamatan yang sudah ada pada halaman tempat sebelumnya dan kita bisa mengedit maupun menghapus data yang diinginkan.

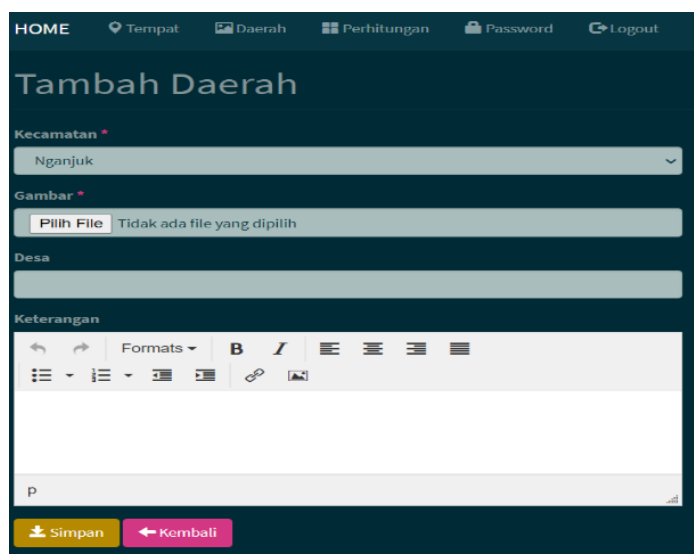

Gambar 8. Halaman Tambah Daerah

Pada halaman ini kita akan menambah daerah desa pada list kecamatan yang sudah ada dan dapat menginputkan hasil panen dan keterangan pada daerah tersebut.

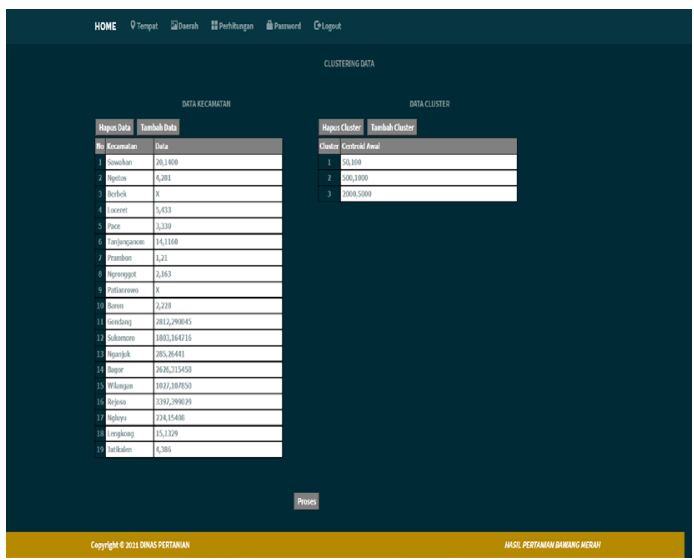

Gambar 9. Perhitungan Data

Halaman perhitungan dapat menghitung data pada kecamatan yang dimasukkan dan mencari masing-masing cluster pada data tersebut.

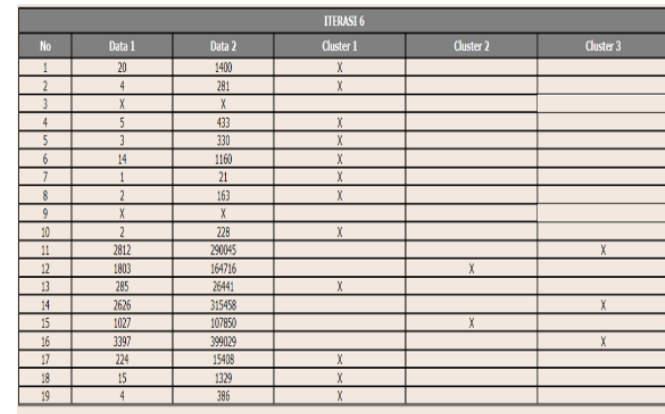

Cluster $1 \rightarrow 41.357142857143 \quad 3398.5714285714$ Cluster $2 \rightarrow 1415 \quad 136283$
duster $3 \rightarrow 2045$ Gambar 10. Hasil Perhitungan

Setelah memasukkan data dan menentukan pusat centroid maka dilakukan pemrosesan 
perhitungan cluster dan melakukan iterasi hingga mendapat hasil akhir seperti pada gambar.

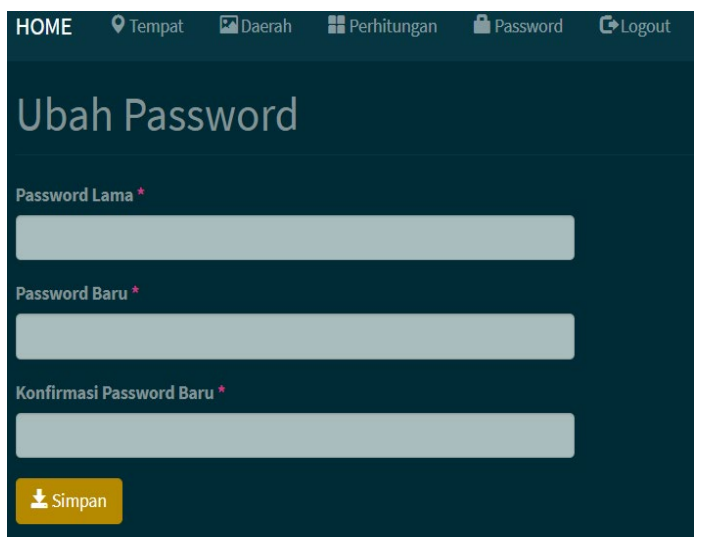

Gambar 11. Ubah Password

Di halaman ini kita bisa mengubah password lama kita dengan password baru yang diinginkan sebagai admin.

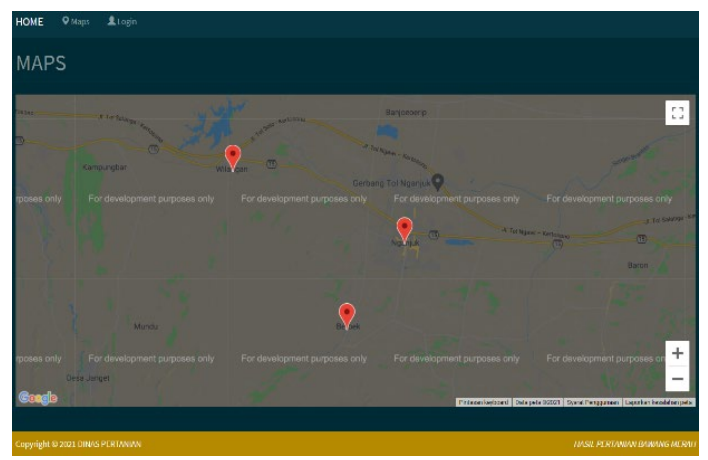

Gambar 12. Maps

Setelah logout sebagai admin maka kita bisa menjadi user biasa yang dapt mengakses halaman maps dimana pada marker yang sudah ada dari data yang kita inputkan sebagai admin akan tampil pada halaman ini dan dapat diklik dan memunculkan detail pada halaman baru.

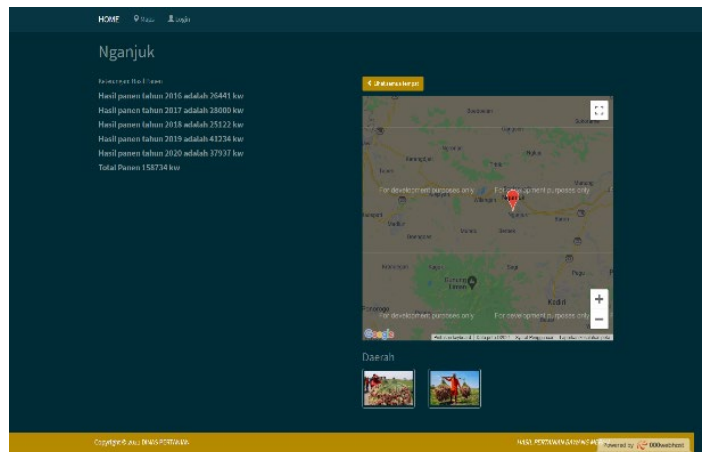

Gambar 13. Halaman Detail
Pada halaman ini kita dapat melihat detail termasuk hasil panen, keterangan dan lokasi pada kecamatan yang sudah diberi marker sebelumnya sebagai admin. Juga memiliki list daerah pada kecamatan tersebut pada tabel daerah sebelumnya.

\section{HASIL DAN PEMBAHASAN}

\subsection{Pembahasan}

Pada pembahasan proses perhitungan dengan metode k-means clustering menggunakan data produksi bawang merah di Kabupaten Nganjuk yang telah diolah menjadi dataset pada periode tahun 20162020 mempunyai sebanyak 19 kecamatan per tahunnya yang merupakan hasil produksi kecamatankecamatan yang ada di Kabupaten Nganjuk, sehingga banyak jumlah data dari tahun 2016 - 2020 yaitu sebanyak 95 kecamatan. Berikut data produksi panen berdasarkan cluster :

Tabel 2. Data Produksi Tahun 2016

\begin{tabular}{|c|c|c|c|c|c|c|c|}
\hline No & Keramattan & Luas Panen & Produksi & Tahun & C1 & $0_{2}$ & $C_{3}$ \\
\hline 1 & Sawahan & 20 & 1400 & 2016 & 1300.346108 & 624.8199741 & 4108.576396 \\
\hline 2 & Ngetos & 4 & 281 & 2016 & 186.7538487 & 873.4853455 & $\begin{array}{r}5123.76599 \\
\end{array}$ \\
\hline 3 & Berbek & - & . & 2016 & . & - & - \\
\hline 4 & Loceret & 5 & 433 & 2016 & 336.026784646 & 75.671243 & 4983.74912 .2 \\
\hline 5 & Pace & 3 & 330 & 2016 & 234.7530617 & 834.2116039 & 5079.065761 \\
\hline 6 & Tanjunganor & 14 & 1160 & 2016 & 1060.611145 & 511.6600434 & 4323.166671 \\
\hline 7 & Prambon & 1 & 21 & 2016 & 92.96235797 & 1098.836658 & 53665.298805 \\
\hline 8 & Ngrongegot & 2 & 163 & 2016 & 79.2027769 & 973.9471388 & 973.4711238 \\
\hline 9 & Patianrove & - & . & 2016 & $\cdot$ & 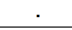 & $\cdot$ \\
\hline 10 & Baron & 2 & 228 & 2016 & 136.70005999 & 918,6881952 & $\$ 173.392311$ \\
\hline 11 & Gondang & 2812 & 290045 & 2016 & 289958.155 & 280054.2464 & 285046.1566 \\
\hline 12 & Sukomoro & 1803 & 164716 & 2016 & 164625.33356 & 163221.1.1851 & $\begin{array}{l}159716.1215 \\
\end{array}$ \\
\hline 13 & Nganjuk & 285 & 26441 & 2016 & 26342.04825 & 25441.90846 & 21509.47945 \\
\hline 14 & Bagor & 2626 & 315458 & 2016 & 315368.32088 & 314455.1867 & 310488.6311. \\
\hline 15 & Wilangan & 1027 & 107850 & 2016 & 107754.4293 & 106851.2996 & 102854,6024 \\
\hline 16 & Rejoso & 3397 & 399029 & 2016 & 398943.0404 & 398039.5426 & 394031.1765 \\
\hline 17 & Ngluyu & 224 & 15408 & 2016 & 15308.98886 & 14410.64329 & 10558.43928 \\
\hline 18 & Lenglong & 15 & 1329 & 2016 & 1229.498272 & 586.0597239 & 4173.303967 \\
\hline 19 & thalale & 4 & 386 & 2016 & 289.6756807 & 789.311109 & 502 \\
\hline
\end{tabular}

Tabel 3. Data Produksi Tahun 2017

\begin{tabular}{|c|c|c|c|c|c|c|c|}
\hline No & Kecamattan & Luss Panen & Produksi & Tahun & $\mathrm{Cl}$ & C2 & $c 3$ \\
\hline 1 & Sawahan & 9 & 630 & 2017 & 531.5834836 & 611.801594 & 4802.188024 \\
\hline 2 & Ngetos & . & . & 2017 & . & . & . \\
\hline 3 & Berbek & . & . & 2017 & . & . &. \\
\hline 4 & Loceret & 11 & 1480 & 2017 & 1380.550977 & 685.2160243 & 4043.083106 \\
\hline 5 & Pace & 3 & 360 & 2017 & 264.2139285 & 810.3141366 & 5051.495719 \\
\hline 6 & Tariunganaron & 22 & 2122 & 2017 & 2022193858 & 1219,576996 & 3492.186607 \\
\hline 7 & Prambon & 6 & 488 & 2017 & 390.4688756 & 711.4628280 & 4932.96868 \\
\hline 8 & Ngrongegot & . & . & 2017 & . & . & . \\
\hline 9 & Patáanowo & - & . & 2017 & . & . & . \\
\hline 10 & Baron & 7 & 838 & 2017 & 739.25164860 & 518.9344853 & 4661.5753978 \\
\hline 11 & Gondang & 3033 & 284607 & 2017 & 284522.6377 & 283618.3114 & 279608.9082 \\
\hline 12 & Sukomoro & 1116 & 79737 & 2017 & 79644.13428 & 78739.40961 & 77742.27876 \\
\hline 13 & Nganjuk & 301 & 28000 & 2017 & 27901.12003 & 270000.73334 & 23062606682 \\
\hline 14 & Bagor & 2527 & 306520 & 2017 & 306430.0115 & 305526.7241 & 301520.4605 \\
\hline 15 & Wilangan & 996 & 110272 & 2017 & 110176.0614 & 109973.1257 & 105276.67876 \\
\hline 16 & Rejoso & 3786 & 433978 & 2017 & 433894,0845 & 432900.469 & 428981.7179 \\
\hline 17 & Neluyu & 275 & \begin{tabular}{|l|l|}
19027 \\
\end{tabular} & 2017 & 18928.37373 & 18028.4040199 & 14132.60974 \\
\hline 18 & Lenglong & 10 & 715 & 2017 & 616.2994402 & 566.8535007 & 4724.54952 \\
\hline 19 & Jatiklen & 19 & 1262 & 2017 & 1162.413438 & 547.72711218 & 4230.485197 \\
\hline
\end{tabular}


Tabel 4. Data Produksi Tahun 2018

\begin{tabular}{|c|c|c|c|c|c|c|c|}
\hline № & Kecamatitn & Luas Panen & Produksi & Tahun & C1 & 02 & $C 3$ \\
\hline 1 & Sawahan & 13 & 902 & 2018 & 802.8530376 & 496,7625187 & 4554.3136609 \\
\hline 2 & Ngetos & 5 & 375 & 2018 & 278.6574599 & 797.2766145 & 5036.986808 \\
\hline 3 & Berbek & . & & 2018 & . &. & . \\
\hline 4 & Loceret & 2 & 125 & 2018 & 54.12023651 & 1006.791438 & 5668.55039 \\
\hline 5 & Pace & & & 2018 & . & . & . \\
\hline 6 & Taningraganor & 39 & 4990 & 2018 & 4090.014792 & 3223.138377 & 2121.702383 \\
\hline 7 & Prambon & 9 & 685 & 2018 & $586 .+4349921$ & 5883.3575233 & 47521189601 \\
\hline 8 & Ngronggot & . & . & 2018 &. & . & . \\
\hline 9 & Patianrowo & & & 2018 & . & . & . \\
\hline 10 & Baron & 5 & 425 & 2018 & 328.1055943 & 758.71602027 & 4991.057002 \\
\hline 11 & Gondang & 3392 & 342472 & 2018 & 34388833108 & 344484.2463 & 337474.8708 \\
\hline 12 & Sulkomero & 1579 & 179035 & 2018 & 198841.5325 & 178038.6697 & 17400355092 \\
\hline 13 & Nganiuk & 216 & 25122 & 2018 & 25022.55063 & 24123.67178 & 202000.92919 \\
\hline 14 & Bagor & 3088 & 351873 & 2018 & 351786.1182 & 35088254443 & 346874,7063 \\
\hline 15 & Wilangan & 812 & 104907 & 2018 & 104809,77 & 103907,4684 & 9991.06304 \\
\hline 16 & Rejoso & 4054 & 488640 & 2018 & 488566.4078 & 487652.9509 & $48364+3.3610$ \\
\hline 17 & Negluy & 265 & 19750 & 2018 & 19651.17617 & 18751.47261 & 14851.60989 \\
\hline 18 & Lenglong & 33 & 2703 & 2018 & 26030.055512 & 1765.870324 & 3024.119376 \\
\hline 19 & Jatiklelen & 29 & 2880 & 2018 & 2780.079315 & 1938.102422 & 28946.691860 \\
\hline
\end{tabular}

Tabel 5. Data Produksi Tahun 2019

\begin{tabular}{|c|c|c|c|c|c|c|c|}
\hline No & Kecamatan & Luas Panen & Produksi & Tahun & $\mathrm{Cl}$ & $C_{2}$ & $C_{3}$ \\
\hline 1 & Sawahan & 4 & 355 & 2019 & 259.1158042 & 813.6590195 & 5055.6393919 \\
\hline 2 & Ngetos & 1 & 90 & 2019 & 50.009999 & 1037.837765 & 5301.330116 \\
\hline 3 & Berbek & 5 & 620 & 2019 & 521.9434835 & 624.0.0392616 & 48129434386 \\
\hline 4 & Loceret & 31 & 3860 & 2019 & 3760.048005 & 2888.199614 & 2275.205705 \\
\hline 5 & Pace & 9 & 880 & 2019 & 781.0768208 & 505.4512835 & 47578.858499 \\
\hline 6 & Tanjungangon & 11 & 1450 & 2019 & 1350,063216 & 664.5457095 & 4069,228551 \\
\hline 7 & Prambon & 14 & 1460 & 2019 & 1360.476387 & 669.1756122 & 4059.038802 \\
\hline 8 & Negrongegot & - & - & 2019 & . & . & - \\
\hline 9 & Patianrowo & 2 & 100 & 2019 & 48 & 1028.593214 & 5291.691979 \\
\hline 10 & Baron & 3 & 300 & 2019 & 205.4482903 & 858.492283 & 5106.663196 \\
\hline 11 & Gondang & 2693 & 310934 & 2019 & 310845.2364 & 309941.7984 & 305934.7849 \\
\hline 12 & Sukomero & 1703 & 205225 & 2019 & 205201.658 & 204298.5419 & 200295.20202 \\
\hline 13 & Nganiuk & 359 & 41234 & 2019 & 41.135 .16059 & 40234.24707 & 36271.14055 \\
\hline 14 & Bagor & 3217 & 347585 & 2019 & 347499,4318 & 346599.64966 & 342887,1616 \\
\hline 15 & Wilangan & 780 & 114350 & 2019 & 114252.3321 & 113350.3458 & 109356.8055 \\
\hline 16 & Rejoso & 4730 & 570930 & 2019 & 570849.1844 & 569945.6972 & 5659396.5846 \\
\hline 17 & Noluyu & 265 & 20895 & 2019 & 20796.11142 & 19896.38786 & 15989.41056 \\
\hline 18 & Lengkong & 19 & 2541 & 2019 & 2441.196838 & 1614.324007 & 3157.695679 \\
\hline 19 & Jatiklan & 15 & 1620 & 2019 & 1520.402907 & 787.16262661 & 3919,77359 \\
\hline
\end{tabular}

Tabel 6. Data Produksi Tahun 2020

\begin{tabular}{|c|c|c|c|c|c|c|c|}
\hline No & Kecamatan & Luas Panen & Produksi & Tehun & C1 & $C_{2}$ & C3 \\
\hline 1 & Sawahan & 5 & 575 & 2020 & 477.1268175 & 652.4185773 & 4853.931396 \\
\hline 2 & Ngetos & - & - & 2020 & & & \\
\hline 3 & Berbek & 3 & 200 & 2020 & 110,9933437 & 941.8115523 & $5198.84689]$ \\
\hline 4 & Loceret & 38 & 3482 & 2020 & 3382.01289 & 2524.63225 & 2480.688399 \\
\hline 5 & Pace & 6 & 555 & 2020 & 457.1225219 & 664.8766803 & 4871.761591 \\
\hline 6 & Tanjunganon & 13 & 1730 & 2020 & 1630.419885 & 877.5357543 & 3866.364985 \\
\hline 7 & Prambon & 13 & 1288 & 2020 & 1188.576039 & 565.785295 & 4210.357823 \\
\hline 8 & Ngrongegot & 5 & 770 & 2020 & 671.5094336 & 545.8250036 & 4676.849901 \\
\hline 9 & Patianrowo & - & - & 2020 & . & . & $\cdot$ \\
\hline 10 & Baron & 3 & 370 & 2020 & 274.0602124 & 802.4394058 & 5042.311871 \\
\hline 11 & Gondang & 2975 & 310415 & 2020 & 310328.7851 & 309424.8986 & $30.416,56363$ \\
\hline 12 & Silkomoro & 1410 & 163370 & 2020 & 163377.6641 & 162372.55 & 158871.0999 \\
\hline 13 & Nganajuk & 364 & 37937 & 2020 & 37838.30288 & 36937.25037 & 32977.00551 \\
\hline 14 & Bagor & 3049 & 334914 & 2020 & 334827.4311 & 333923.729 & 329915.6677 \\
\hline 15 & Wilangan & 805 & 116325 & 2020 & 116227.45222 & 115325.40333 & 111331.4136 \\
\hline 16 & Rejesso & 5318 & 720423 & 2020 & 700342.2632 & 719439,133 & $715430.6941]$ \\
\hline 17 & Ngeluyu & 469 & 35320 & 2020 & 35222.49226 & 34320.014 & 30358.6291 \\
\hline 18 & Lenglong & 17 & 1694 & 2020 & 1594.341557 & 845.53233767 & 3855.11673 \\
\hline 19 & Jatiklalen & 12 & 1240 & 2020 & 1140.633158 & 543.8235008 & 42333.203969 \\
\hline
\end{tabular}

\subsection{Hasil Produksi}

Hasil perhitungan menggunakan data produksi bawang merah di Kabupaten Nganjuk tahun 2016 2020 menghasilkan :
1. Produksi 2016

Tabel 7. Hasil Cluster Tahun 2016

\begin{tabular}{|c|l|c|c|}
\hline No & Kecamatan & Cluster & Tahun \\
\hline 1 & Sawahan & $\mathrm{C} 2$ & 2016 \\
\hline 2 & Ngetos & $\mathrm{C} 1$ & 2016 \\
\hline 3 & Berbek & - & 2016 \\
\hline 4 & Loceret & $\mathrm{C} 1$ & 2016 \\
\hline 5 & Pace & $\mathrm{C} 1$ & 2016 \\
\hline 6 & Tanjunganom & $\mathrm{C} 2$ & 2016 \\
\hline 7 & Prambon & $\mathrm{C} 1$ & 2016 \\
\hline 8 & Ngronggot & $\mathrm{C} 1$ & 2016 \\
\hline 9 & Patianrowo & - & 2016 \\
\hline 10 & Baron & $\mathrm{C} 1$ & 2016 \\
\hline 11 & Gondang & $\mathrm{C} 3$ & 2016 \\
\hline 12 & Sukomoro & $\mathrm{C} 3$ & 2016 \\
\hline 13 & Nganjuk & $\mathrm{C} 3$ & 2016 \\
\hline 14 & Bagor & $\mathrm{C} 3$ & 2016 \\
\hline 15 & Wilangan & $\mathrm{C} 3$ & 2016 \\
\hline 16 & Rejoso & $\mathrm{C} 3$ & 2016 \\
\hline 17 & Ngluyu & $\mathrm{C} 3$ & 2016 \\
\hline 18 & Lengkong & $\mathrm{C} 2$ & 2016 \\
\hline 19 & Jatikalen & $\mathrm{C} 1$ & 2016 \\
\hline
\end{tabular}

2. Produksi 2017

Tabel 8. Hasil Cluster Tahun 2017

\begin{tabular}{|c|l|c|c|}
\hline No & Kecamatan & Cluster & Tahun \\
\hline 1 & Sawahan & C1 & 2017 \\
\hline 2 & Ngetos & - & 2017 \\
\hline 3 & Berbek & - & 2017 \\
\hline 4 & Loceret & C2 & 2017 \\
\hline 5 & Pace & C1 & 2017 \\
\hline 6 & Tanjunganom & C2 & 2017 \\
\hline 7 & Prambon & C1 & 2017 \\
\hline 8 & Ngronggot & - & 2017 \\
\hline 9 & Patianrowo & - & 2017 \\
\hline 10 & Baron & C2 & 2017 \\
\hline 11 & Gondang & C3 & 2017 \\
\hline 12 & Sukomoro & C3 & 2017 \\
\hline 13 & Nganjuk & C3 & 2017 \\
\hline 14 & Bagor & C3 & 2017 \\
\hline 15 & Wilangan & C3 & 2017 \\
\hline 16 & Rejoso & C3 & 2017 \\
\hline 17 & Ngluyu & C3 & 2017 \\
\hline 18 & Lengkong & C2 & 2017 \\
\hline 19 & Jatikalen & C2 & 2017 \\
\hline & & & \\
\hline
\end{tabular}

3. Produksi 2018

Tabel 9. Hasil Cluster Tahun 2018

\begin{tabular}{|c|l|c|c|}
\hline No & Kecamatan & Cluster & Tahun \\
\hline 1 & Sawahan & C2 & 2018 \\
\hline 2 & Ngetos & C1 & 2018 \\
\hline 3 & Berbek & - & 2018 \\
\hline 4 & Loceret & C1 & 2018 \\
\hline 5 & Pace & - & 2018 \\
\hline 6 & Tanjunganom & C3 & 2018 \\
\hline 7 & Prambon & C2 & 2018 \\
\hline 8 & Ngronggot & - & 2018 \\
\hline 9 & Patianrowo & - & 2018 \\
\hline 10 & Baron & C1 & 2018 \\
\hline 11 & Gondang & C3 & 2018 \\
\hline 12 & Sukomoro & C3 & 2018 \\
\hline 13 & Nganjuk & C3 & 2018 \\
\hline 14 & Bagor & C3 & 2018 \\
\hline 15 & Wilangan & C3 & 2018 \\
\hline 16 & Rejoso & C3 & 2018 \\
\hline 17 & Ngluyu & C3 & 2018 \\
\hline 18 & Lengkong & C2 & 2018 \\
\hline 19 & Jatikalen & C2 & 2018 \\
\hline & & & \\
\hline
\end{tabular}


4. Produksi 2019

Tabel 10. Hasil Cluster Tahun 2019

\begin{tabular}{|c|l|c|c|}
\hline No & Kecamatan & Cluster & Tahun \\
\hline 1 & Sawahan & $\mathrm{C} 1$ & 2019 \\
\hline 2 & Ngetas & $\mathrm{C} 1$ & 2019 \\
\hline 3 & Berbek & $\mathrm{C} 1$ & 2019 \\
\hline 4 & Loceret & $\mathrm{C} 3$ & 2019 \\
\hline 5 & Pace & $\mathrm{C} 2$ & 2019 \\
\hline 6 & Tanjunganom & $\mathrm{C} 2$ & 2019 \\
\hline 7 & Prambon & $\mathrm{C} 2$ & 2019 \\
\hline 8 & NgrangBot & - & 2019 \\
\hline 9 & Patianrowo & $\mathrm{C} 1$ & 2019 \\
\hline 10 & Baron & $\mathrm{C} 1$ & 2019 \\
\hline 11 & Gondang & $\mathrm{C} 3$ & 2019 \\
\hline 12 & Sukomoro & $\mathrm{C} 3$ & 2019 \\
\hline 13 & Nganjuk & $\mathrm{C} 3$ & 2019 \\
\hline 14 & Bagor & $\mathrm{C} 3$ & 2019 \\
\hline 15 & Wilangan & $\mathrm{C} 3$ & 2019 \\
\hline 16 & Rejosa & $\mathrm{C} 3$ & 2019 \\
\hline 17 & Ngluyu & $\mathrm{C} 3$ & 2019 \\
\hline 18 & Lengkong & $\mathrm{C} 2$ & 2019 \\
\hline 19 & Jatikalen & $\mathrm{C} 2$ & 2019 \\
\hline
\end{tabular}

5. Produksi 2020

Tabel 11. Hasil Cluster Tahun 2020

\begin{tabular}{|c|l|c|c|}
\hline No & Kecamatan & Cluster & Tahun \\
\hline 1 & Sawahan & C1 & 2020 \\
\hline 2 & Ngetos & - & 2020 \\
\hline 3 & Berbek & C1 & 2020 \\
\hline 4 & Loceret & C3 & 2020 \\
\hline 5 & Pace & C1 & 2020 \\
\hline 6 & Tanjunganom & C2 & 2020 \\
\hline 7 & Prambon & C2 & 2020 \\
\hline 8 & Ngronggot & C2 & 2020 \\
\hline 9 & Patianrowo & - & 2020 \\
\hline 10 & Baron & C1 & 2020 \\
\hline 11 & Gondang & C3 & 2020 \\
\hline 12 & Sukomoro & C3 & 2020 \\
\hline 13 & Nganjuk & C3 & 2020 \\
\hline 14 & Bagor & C3 & 2020 \\
\hline 15 & Wilangan & C3 & 2020 \\
\hline 16 & Rejoso & C3 & 2020 \\
\hline 17 & Ngluyu & C3 & 2020 \\
\hline 18 & Lengkong & C2 & 2020 \\
\hline 19 & Jatikalen & C2 & 2020 \\
\hline
\end{tabular}

Tabel 7,8,9,10 dan 11 merpakan tabel hasil cluster produksi bawang merah di kecamatan yang ada di Kabupaten Nganjuk dari tahun 2016-2020.

Keterangan :

C1 : kecamatan dengan produksi bawang merah sedikit.

C2 : kecamatan dengan produksi bawang merah sedang.

C3 : kecamatan dengan produksi bawang merah banyak.

Dengan total banyak masing-masing cluster :

$\mathrm{C} 1=22, \mathrm{C} 2=22$, dan $\mathrm{C} 3=38$

Dimana hasil yang paling banyak yaitu C3 dikatakan produksi bawang merah banyak.

\subsection{Pengujian Sistem}

Pengujian sistem ini dilakukan guna mengetahui apakah sistem sudah berjalan dengan baik sesuai dengan yang diharapkan, pengujian yang dilakukan adalah pengujian fungsionalitas website lalu pengguna mengisi kuesioner sesuai hasil yang didapatkan dari pengujian, dilakukan oleh 9 user dan kuesioner berisi 6 pertanyaan tentang website yang dibuat.
Tabel 12. Hasil Pengujian Fungsionalitas Sistem Pada

\begin{tabular}{|c|c|c|c|c|c|}
\hline \multicolumn{6}{|c|}{ Weebsite } \\
\hline $\begin{array}{l}\mathbf{N} \\
\mathbf{0}\end{array}$ & $\begin{array}{l}\text { Skenario } \\
\text { Pengujian }\end{array}$ & Test Case & $\begin{array}{c}\text { Hasil yang } \\
\text { Diharapkan }\end{array}$ & $\begin{array}{c}\text { Hasil } \\
\text { Penguji } \\
\text { an }\end{array}$ & $\begin{array}{c}\text { Kesi } \\
\text { mpul } \\
\text { an }\end{array}$ \\
\hline 1 & $\begin{array}{l}\text { Pada menu } \\
\text { maps pilih } \\
\text { kecamatan } \\
\text { lalu menuju } \\
\text { detail dan } \\
\text { menampilk } \\
\text { an data } \\
\text { serta lokasi } \\
\text { daerah } \\
\text { tersebut. }\end{array}$ & $\begin{array}{lr}\text { Klik } & \text { menu } \\
\text { map } & \text { dan } \\
\text { detail } & \text { untuk } \\
\text { data lengkap }\end{array}$ & $\begin{array}{l}\text { Menampilka } \\
\mathrm{n} \text { lokasi } \\
\text { setiap } \\
\text { kecamatan } \\
\text { pada maps } \\
\text { dan } \\
\text { melihat detail } \\
\text { pada masing- } \\
\text { masing } \\
\text { kecamatan. }\end{array}$ & $\begin{array}{c}\text { Sesuai } \\
\text { harapan }\end{array}$ & $\begin{array}{c}\text { Berh } \\
\text { asil }\end{array}$ \\
\hline 2 & $\begin{array}{l}\text { Menjalanka } \\
\mathrm{n} \text { website } \\
\text { pada } \\
\text { platform pc }\end{array}$ & $\begin{array}{l}\text { Membuka } \\
\text { website } \\
\text { menggunaka } \\
\text { n pc }\end{array}$ & $\begin{array}{l}\text { Website } \\
\text { dapat } \\
\text { dijalankan } \\
\text { pada } \\
\text { platform PC }\end{array}$ & $\begin{array}{c}\text { Sesuai } \\
\text { harapan }\end{array}$ & $\begin{array}{c}\text { Berh } \\
\text { asil }\end{array}$ \\
\hline 3 & $\begin{array}{l}\text { Pada detail } \\
\text { menampilk } \\
\text { an data } \\
\text { panen } \\
\text { bawang } \\
\text { merah serta } \\
\text { letak lokasi } \\
\text { pada } \\
\text { kecamatan } \\
\text { yang } \\
\text { dipilih. }\end{array}$ & \begin{tabular}{l} 
Klik mark \\
pada maps \\
lalu pilih \\
detail pada \\
kecamatan \\
\multicolumn{2}{l}{ yang dipilih }
\end{tabular} & $\begin{array}{l}\text { Melihat } \\
\text { detail pada } \\
\text { masing- } \\
\text { masing } \\
\text { kecamatan. }\end{array}$ & $\begin{array}{c}\text { Sesuai } \\
\text { harapan }\end{array}$ & $\begin{array}{c}\text { Berh } \\
\text { asil }\end{array}$ \\
\hline 4 & $\begin{array}{l}\text { Membuka } \\
\text { semua } \\
\text { lokasi pada } \\
\text { maps yang } \\
\text { memiliki } \\
\text { tanda } \\
\text { (mark). }\end{array}$ & $\begin{array}{lr}\text { Klik } & \text { menu } \\
\text { maps } & \text { lalu } \\
\text { pilih } & \text { semua } \\
\text { mark } & \text { yang } \\
\text { ada } & \text { pada } \\
\text { maps. } & \\
\end{array}$ & $\begin{array}{l}\text { Menampilka } \\
\mathrm{n} \quad \text { lokasi } \\
\text { setiap } \\
\text { kecamatan } \\
\text { pada maps. }\end{array}$ & $\begin{array}{c}\text { Sesuai } \\
\text { harapan }\end{array}$ & $\begin{array}{c}\text { Berh } \\
\text { asil }\end{array}$ \\
\hline 5 & $\begin{array}{l}\text { Menjalanka } \\
\mathrm{n} \text { website } \\
\text { pada } \\
\text { platform } \\
\text { mobile. }\end{array}$ & $\begin{array}{l}\text { Membuka } \\
\text { website } \\
\text { menggunaka } \\
\mathrm{n} \quad \text { mobile } \\
\text { (HP). }\end{array}$ & $\begin{array}{l}\text { Dapat } \\
\text { menjalankan } \\
\text { website pada } \\
\text { platform } \\
\text { mobile. }\end{array}$ & $\begin{array}{c}\text { Sesuai } \\
\text { harapan }\end{array}$ & $\begin{array}{c}\text { Berh } \\
\text { asil }\end{array}$ \\
\hline 6 & $\begin{array}{l}\text { Menampilk } \\
\text { an daerah } \\
\text { (desa) pada } \\
\text { detail } \\
\text { kecamatan } \\
\text { yang } \\
\text { dipilih. }\end{array}$ & $\begin{array}{l}\text { Pada } \\
\text { halaman } \\
\text { detail } \\
\text { kecamatan } \\
\text { pilih gambar } \\
\text { desa yang } \\
\text { terdapat di } \\
\text { bawah lokasi } \\
\text { atau maps } \\
\text { kecamatan. }\end{array}$ & $\begin{array}{l}\text { Dapat } \\
\text { menampilka } \\
\text { n setiap desa } \\
\text { pada } \\
\text { kecamatan } \\
\text { yang dipilih. }\end{array}$ & $\begin{array}{c}\text { Sesuai } \\
\text { harapan }\end{array}$ & $\begin{array}{c}\text { Berh } \\
\text { asil }\end{array}$ \\
\hline 7 & $\begin{array}{l}\text { Memperbes } \\
\text { ar dan } \\
\text { memperkec } \\
\text { il maps } \\
\text { untuk } \\
\text { melihat } \\
\text { lebih jelas } \\
\text { lokasi } \\
\text { kecamatan. }\end{array}$ & $\begin{array}{l}\text { Gunakan } \\
\text { scroll up and } \\
\text { down untuk } \\
\text { memperbesar } \\
\text { dan } \\
\text { memperkecil } \\
\text { maps. }\end{array}$ & $\begin{array}{l}\text { Maps dapat } \\
\text { diperbesar } \\
\text { dan } \\
\text { diperkecil. }\end{array}$ & $\begin{array}{c}\text { Sesuai } \\
\text { harapan }\end{array}$ & $\begin{array}{c}\text { Berh } \\
\text { asil }\end{array}$ \\
\hline 8 & $\begin{array}{l}\text { Mencoba } \\
\text { login } \\
\text { dengan } \\
\text { back page } \\
\text { setelah } \\
\text { admin } \\
\text { logout. }\end{array}$ & $\begin{array}{l}\text { Setelah } \\
\text { admin logout } \\
\text { user mencoba } \\
\text { klik back } \\
\text { page untuk } \\
\text { kembali } \\
\text { menjadi akun } \\
\text { admin. }\end{array}$ & $\begin{array}{l}\text { Kembali ke } \\
\text { halaman } \\
\text { home karena } \\
\text { gagal } \\
\text { menggunaka } \\
\mathrm{n} \text { login } \\
\text { ilegal. }\end{array}$ & $\begin{array}{c}\text { Sesuai } \\
\text { harapan }\end{array}$ & $\begin{array}{c}\text { Berh } \\
\text { asil }\end{array}$ \\
\hline
\end{tabular}

\subsection{Pengujian User}

Pengujian user diperlukan untuk mengetahui tingkat kepuasan pengguna terhadap pengalaman pengguna dan tampilan antarmuka aplikasi. 
Tabel 13. Tabel Pengujian Pengguna

\begin{tabular}{|c|c|c|c|c|c|}
\hline \multirow[b]{2}{*}{ NO } & \multirow[b]{2}{*}{ Pertanyaan } & \multicolumn{4}{|c|}{9 Pengguna } \\
\hline & & SS & $\mathbf{S}$ & KS & TS \\
\hline 1 & $\begin{array}{l}\text { Website SIG panen bawang } \\
\text { merah memiliki tampilan yang } \\
\text { menarik. }\end{array}$ & 2 & 7 & & \\
\hline 2 & $\begin{array}{l}\text { Website SIG panen } \\
\text { merah dapat diakses } \\
\text { platform PC dan mobile. }\end{array}$ & 9 & & & \\
\hline 3 & $\begin{array}{l}\text { Fitur MAPS pada website dapat } \\
\text { dijalankan dengan lancar. }\end{array}$ & 9 & & & \\
\hline 4 & $\begin{array}{l}\text { Website memudahkan pengguna } \\
\text { mengetahui dearah penghasil } \\
\text { panen bawang merah. }\end{array}$ & 9 & & & \\
\hline 5 & $\begin{array}{l}\text { Pengguna tertarik untuk } \\
\text { mengujungi lagi website } \text { SIG } \\
\text { panen bawang merah. }\end{array}$ & 6 & 3 & & \\
\hline 6 & $\begin{array}{l}\text { Website tidak memiliki suatu } \\
\text { kendala tertentu. }\end{array}$ & 9 & & & \\
\hline & Total & 44 & 10 & & \\
\hline
\end{tabular}

Keterangan :

SS = Sangat Setuju

$\mathrm{S} \quad=$ Setuju

KS $\quad=$ Kurang Setuju

TS $\quad=$ Tidak Setuju

Berdasarkan hasil pengujian user diketahui bahwa mayoritas user menilai aplikasi sudah baik. Dengan demikian aplikasi yang dikembangkan telah sesuai dengan harapan user.

\section{KESIMPULAN DAN SARAN}

\subsection{Kesimpulan}

Kesimpulan yang dapat penulis sampaikan setelah penelitian ini antara lain yaitu:

1. Dari permasalahan diatas tentang data produksi tanaman bawang merah di Kabupaten Nganjuk dapat diselesaikan dengan metode algoritma kmeans menggunakan aturan clustering untuk mengelompokkan daerah potensial tanaman bawang merah di Kabupaten Nganjuk.

2. Pada proses perhitungan dengan metode kmeans clustering menggunakan data produksi bawang merah di Kabupaten Nganjuk yang telah diolah menjadi dataset pada periode tahun 2016 sampai 2020 mempunyai sebanyak 19 data kecamatan per tahunnya, sehingga banyak jumlah data dari tahun 2016 - 2020 yaitu sebanyak 95 kecamatan tetapi masih ada beberapa kecamatan yang tidak menghasilkan panen bawang merah sama sekali pada tahun tertentu.

3. Website GIS yang penulis rancang dapat memudahkan penyelesaian tugas pengelompokkan dengan menggunakan algoritma K-Means. Hasil analisis kelayakan website yang telah dijelaskan diatas maka dapat disimpulkan bahwa website layak untuk diimplementasikan pada Dinas Pertanian di Kabupaten Nganjuk.

\subsection{Saran}

1. Untuk memaksimalkan proses clustering, data yang digunakan lebih banyak agar mendapatkan hasil clustering yang lebih maksimal.

2. Penelitian selanjutnya dapat dikembangkan pada jenis data yang serupa dengan metode yang lebih baik seperti menggunakan algoritma FUZZY C-MEANS.

3. Hasil perhitungan clustering yang diperoleh dapat lebih ditingkatkan dan dikembangkan lagi menjadi basis pengetahuan untuk sistem pendukung keputusan maupun sistem rekomendasi daerah yang cocok untuk ditanami bawang merah oleh dinas pertanian.

\section{DAFTAR PUSTAKA}

[1] Heribertus Giyanto, "Penerapan algoritma Clustering K-Means, K-Medoid, Gath Geva," 2008.

[2] Henri Harianja, "Visualisasi K-Means Clustering Pada Data Potensi Pertanian Desa di Bogor Menggunakan Mapserver," 2008.

[3] Siswanto. 2012. Sistem Informasi Objek Pariwisata Menggunakan Google Maps API Studi Kasus Kabupaten Mojokerto. Surabaya. Jurusan Teknik Informatika. Politeknik Elektronika Negeri Surabaya. Institute Teknologi Sepuluh Nopember.

[4] Effendy, I. (2017). SISTEM INFORMASI PEMETAAN DAERAH PERTANIAN (STUDI KASUS : KOTA LUBUKLINGGAU). Jurnal Informanika, 3(1), 81-91.

[5] Susanto, A., Kharis, A., Khotimah, T. (2016). SISTEM INFORMASI GEOGRAFIS PEMETAAN LAHAN PERTANIAN DAN KOMODITI HASIL PANEN KABUPATEN KUDUS. JURNAL INFORMATIKA, 10(2), 1233-1243.

[6] Soelistio, A. T., Wibowo, T. A., Permana, A. G. (2015). APLIKASI SISTEM INFORMASI GEOGRAFIS (SIG) UNTUK PENGELOLAAN PADI DI PULAU JAWA BERBASIS WEB. eProceeding of Applied Science, 1(1), 720-731 